\title{
A favor da revolução: 0 grotesco e a destruição obsessiva como estratégias de produção - um olhar sobre a obra de Jan Svankmajer
}

\author{
Autor: Caio Cesar Costa e Silva \\ Orientador: Prof ${ }^{\mathrm{a}}$. Dr ${ }^{\mathrm{a}}$. Dirce Vasconcellos Lopes
}

\begin{abstract}
Resumo: A virada do século XIX implicou um novo cenário: com as evoluções tecnológicas tudo passou a ser mais rápido, caótico e fragmentado do que anteriormente. Na Europa, centro dessas transformações, as vanguardas artísticas, como o Dadaísmo e o Surrealismo, estremecem todas as áreas do conhecimento; para eles a arte pela arte já não satisfazia mais os ideais artísticos, além de subvertê-la era necessário transformar o mundo. É nesse contexto que o cinema torna-se foco de expressão desses acontecimentos, seu papel como uma nova arte se torna cada vez mais efetivo. Os surrealistas viam no dispositivo um canal para liberar o que convencionalmente era reprimido, permitindo que o inconsciente pudesse vir à tona como num sonho, mesclando o conhecido e o desconhecido, a realidade e o sonho, o cotidiano e o maravilhoso. Entre esses artistas está Jan Švankmajer, que também via no cinema uma forma de expressão para sua arte. Esta dissertação propõe-se a explorar as estratégias utilizadas por Švankmajer na instância da produção, através de uma análise pormenorizada de dois curtasmetragens - "Uma semana tranquila em uma casa" (Tichýtýden v dome) de 1969 e "A Morte do Stalinismo na Boêmia” (Konecstalinismu v Èechách) de 1990 - procurando demonstrar que o cinema pode encadear elementos que operam a favor de um objetivo. Jan Švankmajer mantém uma relação estreita com o modo de pensar surrealista, a estética do grotesco e a destruição obsessiva surgem aqui como elementos de ruptura da realidade é é neles que o cineasta encontra material suficiente para suscitar a inquietação no público.
\end{abstract}

Palavras-chave: Cinema. Surrealismo. Grotesco. Destruição. Jan Švankmajer. 


\title{
In favor of the revolution: the grotesque and the obsessive destruction as strategies of production - a look into the work of Jan Švankmajer
}

\begin{abstract}
The turn of the century led to a new scenario: with all technological developments everything became faster, chaotic and fragmented than before. In Europe, the center of these transformations, the artistic avant-garde, such as Dadaism and Surrealism, tremble all areas of knowledge, the art for art no longer satisfy most their artistic ideals, its subversion was necessary to transform the world. It is in this context that the film becomes focus of expression of these events, their role as a new art becomes increasingly effective. The surrealists saw in the device a channel to release what was conventionally suppressed, allowing that the unconscious could come to the fore as in the dreams, blending the known and the unknown, reality and dream, everyday life and the wonderful. Among these artists are Jan Švankmajer, who also saw in the film a form of expression to his art. This dissertation proposes to explore the strategies used by Švankmajer in the instance of production, through a detailed analysis of two short films - "A quiet week in a house" (TichýTyden v dome), 1969, and "The Death of Stalinism in Bohemia” (Konecstalinismu v Ėechách), 1990 - seeking to demonstrate that cinema can chain elements that operate in favor of a goal. Jan Švankmajer keeps a close relationship with the thinking surrealist, the aesthetics of grotesque and obsessive destruction arise here as breakdown elements of reality and it is there that the filmmaker finds material enough to arouse uneasiness in the public.
\end{abstract}

Keywords: Cinema. Surrealism. Grotesque. Destruction. Jan Švankmajer.

Dissertação completa disponível em: http://www.uel.br/pos/ mestradocomunicacao/wp-content/uploads/DISSERTA\%C3\%87\%C3\%83OCAIO-CESAR-COSTA-E-SILVA.pdf 